\title{
A CRIANÇA NAS I/MA(R)GENS DE INFÂNCIA: DA (IN)VISIBILIDADE AO PROTAGONISMO SOCIAL
}

\author{
Fernanda Mendes Cabral ${ }^{(*)}$ \\ Adelaide Alves Dias ${ }^{(* *)}$
}

Criança e Infância, duas palavras aparentemente sinônimas, no entanto, complexamente diferentes e complementares. Em que se diferem? Em que se aproximam? Ou, como são aproximadas? São questões como estas que nos acompanham e estão presentes em vários trabalhos de pesquisa acadêmica e científica nas Ciências Humanas e Sociais. No entanto, quando tentamos elaborar uma síntese conceptual, nos deparamos com inúmeras possibilidades de representação, o que torna essas questões ainda mais provocativas, pertinentes e atuais.

Dos “sem-fala” à “ciberinfância”, pensar a questão da infância na atualidade requer uma postura teórica transdisciplinar que contemple as multiplicidades do ser criança, além disso, é preciso ter ciência de que cada criança tem sua própria história e que as relações que elas estabelecem entre pares, vão dando também, os contornos do que se conhece hoje como infância ${ }^{1}$, assim, não é possível formular uma única visão de criança e/ou infância, pois elas - as crianças, são múltiplas, plurais, e surpreendentemente, criativas para mostrar outros modos de ser, antes mesmo que seja possível conhecê-las e apreendê-las (DORNELLES, 2005).

O estudo da infância tem sido marcado por variadas concepções e representações acerca do conceito de criança, que ao longo dos séculos foram sendo modificadas em função, principalmente, das necessidades específicas dessa fase de desenvolvimento. Teóricos como Qvortrup (1993),

\footnotetext{
${ }^{(*)}$ Possui Doutorado e Mestrado em Educação pela Universidade Federal da Paraíba (2018; 2008). Atualmente é professora e pesquisadora na Universidade Federal da Paraíba, Centro de Educação, Campus I. É membro do Núcleo de Pesquisas e Estudos sobre a Criança (NUPEC).E-mail: fernandamc.ufpb@gmail.com.

${ }^{(* *)}$ Possui Pós-doutorado em Educação pela Universidade do Estado do Rio de Janeiro (2013-2015), Doutorado em Educação pela Universidade Federal Fluminense (2001) e Mestrado em Psicologia (Psicologia Social) pela Universidade Federal da Paraíba (1992). Atualmente é professora e pesquisadora na Universidade Federal da Paraíba, Centro de Educação, Campus I. Coordenadora do Núcleo de Pesquisas e Estudos sobre a Criança (NUPEC), membro do Fórum Estadual de Educação da Paraíba (FEE-PB) e do Fórum de Educação Infantil da Paraíba (FEIPB). E-mail: adelaide.ufpb@gmail.com.

${ }^{1} \mathrm{O}$ termo infância aqui não é dito e entendido na origem lexical da palavra escrita no singular, tampouco numa unicidade de representação, mas na pluralidade conceitual que esse termo carrega, então, quando tomo o termo infância no singular, referimo-nos ao seu léxico plural, de forma que infância corresponde também, às várias infâncias em suas multiplicidades culturais especificamente, heterogêneas. Da mesma maneira, a palavra criança é representa na particularidade de cada sujeito e na pluralidade dos modos de ser e viver das crianças, dessa maneira, nesta pesquisa, criança e crianças assumem significados que integram tanto o caráter lexical singular quanto o plural, justamente para designar o/s sujeito/s criança/s em suas especificidades.
} 
Corsaro (1997), James, Jenks e Prout (1998), Montandon (2001), Sirota (2001) e Sarmento (2007) contribuíram significativamente, com o avanço desta literatura no mundo. Além destes, no Brasil podemos destacar o estudo clássico de Florestan Fernandes (1979), o pioneiro na discussão científica sobre infância, não só no sentido de ouvir o que as crianças tinham para falar, mas também para ouvi-las criticar as observações que ele fazia.

Esse esforço teórico procurou desconstruir as concepções que desconsideram a infância e a criança em suas especificidades para dar lugar às concepções de criança como sujeito social, que possui suas próprias formas de vida, de desenvolvimento e de significações, o que reforçou, evidentemente, a concepção de infância defendida pela Sociologia da Infância como uma categoria social do tipo geracional,possuidora e produtora de suas próprias culturas, as culturas da infância. Bem como, defende a ideia de criança como indivíduo concreto, que integra essa categoria geracional como sujeito ativo e social, que interpreta e age no mundo.

Partindo desses pressupostos, este artigo reúne parte dos resultados de uma recente pesquisa de Doutorado em Educação, realizada junto ao Programa de Pós-graduação em Educação da Universidade Federal da Paraíba. Tem o objetivo de estabelecer interlocuções epistemológicas e empíricas sobre as concepções de crianças e infâncias em perspectivas fotoetnográficas.

A Fotoetnografia como aporte teórico e metodológico, consiste "no uso da fotografia como uma narrativa imagética capaz de preservar o dado e convergir para o leitor uma informação cultural a respeito do grupo estudado” (ACHUTTI, 1997, p. 14), ou seja, trata-se de uma abordagem fotoetnográfica que procura construir através de imagens, uma forma narrativa da realidade, aproximando as linguagens visuais do universo da escrita, possibilitando ao pesquisador e leitor uma "escritura por inteiro, [isso ocorre] quando se para de recorrer às palavras para se deixar levar em uma viagem visual reveladora, abrigando o inefável que igualmente encerra conhecimento e sentido" (ACHUTTI, 2004, p. 87).

Portanto, este texto inicialmente, discute as concepções de negação e (in)visibilidade que marcaram a imagem da criança pré-sociológica em seus aspectos históricos, culturais e sociais. Em seguida, destaca a nova concepção sociológica de infância que aponta para a imagem da criança protagonista na contemporaneidade e ressalta a Fotoetnografia como perspectiva teóricometodológica para o desenvolvimento de estudos e pesquisas sobre/com crianças. Por fim, apresenta uma narrativa fotoetnográfica de inspiração autobiográfica construída a partir da interlocução entre narrativas escritas e imagéticas realizadas junto a uma criança-sujeito que corroborou para a consolidação da imagem sociológica da criança protagonista. 


\section{A (IN)VISIBILIDADE DA INFÂNCIA NAS I/MA(R)GENS DE CRIANÇA: PRESSUPOSTOS HISTÓRICOS-SOCIAIS DA SOCIOLOGIA DA INFÂNCIA}

De acordo com Abramowicz e Oliveira (2010), o interesse pelos estudos da criança no campo da Sociologia surge em 1920 nos Estados Unidos, no entanto, só a partir de 1980 tomam novas projeções mundiais intensificando-se em pesquisas assinadas por autores como Corsaro, James, Prout, Jenks, Qvortrup e Sirota. Na França, os estudos da criança despontam, inicialmente, no campo da Sociologia da Educação. Na Inglaterra e Estados Unidos são influenciados pelos estudos feministas e pela Antropologia. Todavia, Marchi (2010, p.2) acrescenta que, mesmo com a ampliação das discursões, a infância como objeto sociológico, ainda passou por um longo processo de “apagamento” ou “marginalização”, que a levou a ser ignorada, em sua autonomia conceitual.

No Brasil, em1990, sociólogos e pedagogos, prioritariamente, legitimam o campo, fundamentados em teorias que permeiam desde as perspectivas durkheimianas, em que prevalece, segundo Abramowicz e Oliveira (2010, p. 42, grifo no original), a “imposição dos valores adultos sobre a criança, levando estas a permanecerem no silêncio, 'mudas', ou seja, em uma posição marginalizada e passiva diante do mundo adulto”, até os contributos da “sociologia interacionista, do movimento da fenomenologia e dos approches construcionistas que fornecem os paradigmas teóricos desta nova construção do objeto” (ABRAMOWICZ; OLIVEIRA, 2010, p. 42). O que culmina na perspectiva atual de criança como ator social e infância como estrutura/fenômeno social (QVORTRUP, 1993; CORSARO, 1997; JAMES, JENKS e PROUT, 1998; SIROTA, 2001; SARMENTO, 2007).

James, Jenks e Prout (1998) distinguem criança como agente social e infância como construção social e histórica, resultante da própria ação das crianças em interação com seus pares e com os adultos. Assumem a perspectiva de criança tribal para representar que a ação social da criança estrutura o sistema de representação cultural da infância, a partir de uma visão potencialmente, politizada e empírica da criança em detrimento de suas relações sociais.

Qvortrup (1993), pesquisador dinamarquês, foi um dos grandes responsáveis pela consolidação da nova Sociologia da Infância ao defender as concepções de infância como fenômeno social e da criança como construtora da infância e da sociedade, considerando digno de interesse dos estudos da criança, seus saberes, suas possibilidades de criação e recriação da realidade social em que está inserida. Defendeu também, a ideia de que a infância é uma estrutura social permanente, dessa forma, as crianças passam pela infância, mas, a infância permanece (QVORTRUP, 1993, p. 203). 
Sarmento (2007) defende a tese de que a criação de sucessivas representações das crianças ao longo da História produziu um efeito de (in)visibilização da realidade social da infância, tanto em relação à ideologia, quanto à sua representação imagética no passado. Com isso, sugere o termo (in)visibilidade para representar a ausência da criança nos aspectos histórico, científico e cívico, situações em que a criança era vista a partir do olhar adultocêntrico sobre a infância, registrando especialmente a "ausência, a incompletude ou a negação das características de um ser humano completo” (SARMENTO, 2007, p. 33)².

Portanto, as concepções de negação e (in)visibilidade presente na história social da criança e nas concepções de infância instituídas pelas Ciências Humanas e Sociais, durante séculos foram marcadas, severamente, pelo silêncio e marginalização das crianças, o que inspirou James, Janks e Prout (1998) a sistematizar as concepções de criança a partir de imagens, historicamente, estabelecidas sobre a infância, tais imagens, foram,posteriormente,revisadas por Sarmento (2007).

Basicamente, essas imagens estão divididas em dois grandes períodos: o das imagens da criança pré-sociológica e o das imagens da criança sociológica. O período das imagens da criança pré-sociológica compreende cinco concepções: a da criança má, da criança inocente, da criança imanente, da criança naturalmente desenvolvida e da criança inconsciente.

A primeira imagem da criança pré-sociológica refere-se à criança concebida como uma expressão de forças indomadas, dionisíacas, com potencialidade permanente para o mal - criança má (theevilchild), reforçando as intervenções paternalistas e a adoção de medidas de repressão infantil. De acordo com Sarmento (2007, p. 30), essa imagem fundamenta-se nas obras de Thomas Hobbes, sobre a exigência de controle dos excessos, pelo poder absoluto do Estado sobre os cidadãos e dos pais sobre as crianças, como meio de evitar a anarquia social ou o transbordamento individual.

A segunda imagem da criança pré-sociológica é representada pela imagem da criança inocente, lembra a ideia do mito romântico da "paparicação” apontada para fundamentar a ideia da inocência, da pureza, da bondade e da beleza. Rousseau embasa esta concepção ressaltando que a natureza do homem (quando nasce) é genuinamente boa e a sociedade a perverte, em sua obra “Emílio ou Da Educação” (1995) encontra-se uma grande contribuição para a história social da

${ }^{2}$ QRcode 44: Visibilidade Social e Estudo da Infância (SARMENTO, 2007). 
criança no século XVIII. Rousseau (1999) conquistou o mérito da construção de um conceito moderno de infância marcando a passagem dos séculos XVII e XVIII como o período histórico em que a infância assume um caráter distintivo da adultez e constitui-se como uma fase própria do desenvolvimento humano (SARMENTO, 2007, p.28).

Outra tendência pode ser compreendida a partir da terceira simbolização da criança présociológica apontada por Sarmento (2007, p. 30), a criança imanente.Surge da possibilidade de aquisição da razão e da experiência.Fundamenta-se na teoria da Tábula rasa de Jonh Locke, na qual o conceito passa a ser mais aplicado ao intelecto. Para Locke, não existiam ideias inatas, todo conhecimento se baseava em dados da experiência empírica, nesse sentido, a tendência era a crença na criança como uma tabula rasa em que poderiam ser inscritos quer o vício quer a virtude, a razão ou a desrazão, sendo missão da sociedade promover o crescimento com vista a uma ordem social coesa.

Em se tratando da imagem da criança naturalmente desenvolvida, Sarmento (2007, p. 31) destaca duas ideias centrais, a primeira em que as crianças são seres naturais, antes de serem seres sociais e a segunda que a natureza infantil sofre um processo de maturação que se desenvolve por estágios. Ambas fundamentadas, principalmente, nas contribuições da psicologia do desenvolvimento de Jean Piaget (1979) e Lev Vygotsky (1991).

Em relação à imagem da criança inconsciente, a criança é vista como um preditor do adulto - também conhecido por 'homúnculo’ (SARMENTO, 2007, p. 31). Pautado na Psicanálise, onde Freud é a maior referência, esta imagem social imputa ao inconsciente, o desenvolvimento do comportamento humano com incidência no conflito relacional na idade infantil, especialmente, na relação com as figuras materna e paterna.

De modo contrário, as imagens dacriança sociológicaresultam das produções contemporâneas das Ciências Humanas e Sociais e “constituem, de facto, processos de reinterpretação das representações anteriormente formuladas, com revisão do seu fundamento pela compreensão da categoria geracional” (SARMENTO, 2007, p. 30). Ou seja, surgem da ideia deinfância como possuidora de uma cultura própria e da criança como sujeito que formula e interpreta o mundo de acordo com suas próprias representações. Assim, os sujeitos infantis, enquanto seres sociológicos, (re)produzem os símbolos culturais dando novas configurações que implicam na constituição de suas culturas, além disso, através das relações de alteridade que estabelecem com seus pares e com os adultos, a criança vai desenvolvendo suas expressividades 
culturais através da linguagem, da imaginação, das brincadeiras e das reproduções interpretativas ${ }^{3}$ que elabora (CORSARO, 1997, p. 95).

Todavia, ressalta-se que nenhuma subclassificação é feita pelos autores com relação à criança sociológica, porém, é nela que vamos defender uma nova imagem para a criança sociológica na perspectiva da Sociologia da Infância - a imagem da criança protagonista, que exerce sua participação na sociedade de forma ativa, criativa e reflexiva, que subverte os limites e imposições das culturas visuais e reinventa modos de ser e de viver na contemporaneidade.

\section{A IMAGEM DA CRIANÇA PROTAGONISTA: NOVAS IDENTIDADES PARA A CRIANÇA SOCIOLÓGICA NA CONTEMPORANEIDADE}

O processo de compreensão das atuais concepções de criança e infância assenta-se na ação reflexiva e interpretativa assumida enquanto exercício metodológico que visa desvelar o protagonismo e a alteridade infantil, corroborando assim, para o avanço epistemológico do paradigma social da infância na contemporaneidade através de novas imagens da criança sociológica que emergem na atual ordem social científica. Para Sarmento, "a alteridade da infância constitui um elemento de referenciação do real que se centra numa análise concreta das crianças como atores sociais”, portanto, “A porta de entrada para o estudo da alteridade da infância é a acção das crianças e as ‘culturas da infância”’ (SARMENTO, 2005, p.373, grifo no original).

No entanto, Pires e Branco (2007, p. 312) alertam para o fato de queo termo "protagonismo" está vinculado ao conceito de “participação”, e isso tem gerado muitas divergências quanto ao seu uso, pois, para alguns teóricos, essas palavras são sinônimas e para outros, carregam significados diferentes. Pires e Branco (2007) afirmam que o caráter polissêmico da expressão "protagonismo” se deve,principalmente, a fatores de ordem política, por se tratar de um conceito passível de diferentes interpretações e imbricado em outros conceitos, igualmente, polissêmicos, como participação, responsabilidade social, identidade, autonomia e cidadania. Desse modo, Pires e Branco (2008, p. 416) sugerem que o protagonismo deve exigir uma disposição cooperativa e de colaboração entre adultos e crianças, para isso, torna-se necessário promover a participação.

\footnotetext{
${ }^{3}$ Para Corsaro (1997), o processo de construção das culturas da infância é reprodutivo, interpretativo e criativo. Portanto, as crianças apropriam-se ativamente das informações do mundo adulto para criarem suas próprias formas de viver e de se relacionar. A esse processo de apropriação criativa, Corsaro deu o nome de reprodução interpretativa. Também entendido por “apreensão criativa” da criança (MÜLLER; CARVALHO, 2009, p. 23; MARTINS FILHO; PRADO, 2011, p. 3).
} 
Considerando que a ação da criança, vista pelo prisma da Sociologia da Infância, é crítica, criativa e inteligível, a imagem da criança protagonistaé entendidaaqui como resultado da (des/re)construção das imagens da criança pré-sociológica, debatidas por Sarmento (2007, p.30-33), arquitetada num frame interpretativo que pensou a infância enquanto categoria social, consequência de um processo de reflexividade moderna no âmbito das produções contemporâneas da atual ordem científica no campo das Ciências Humanas e Sociais.

Fundamenta-se nas noções de criança como ator social que cria, reproduz e interpreta o mundo de acordo com suas inteligibilidades, representações e expressões subjetivas, produzindo evidentemente, suas próprias culturas nas relações de alteridade que estabelece nos "entre-lugares”4 que atua e nas "entre-culturas” 5 das quais participa, ou seja, emergem nas múltiplas infâncias que surgem do entrelaçamento de várias culturas e vários lugares.

Conforme proposições epistemológicas da Sociologia da Infância (SARMENTO, 2007), são crianças que impõem suas ações como forma de resistência através da participação social exercida nos espaços ocultos ou libertados da influência adulta, daí, a ideia de criança como ator social.Tal proposição, compõe o universo paradigmático da nova epistemologia da infância que rompe com a perspectiva analítica do adultocentrismo e o princípio da negatividade, e compreende as imagens sociais da infância a partir do próprio protagonismo infantil, expresso na socialização horizontal e nas relações de alteridade geracional.

O texto ora discorrido, apresentou de forma sintética as principais mudanças paradigmáticas da nova Sociologia da Infância visando contextualizar as concepções de crianças pré-sociológicas e sociológicas, para só então, dar continuidade ao texto, apresentando o caráter científico e metodológico da pesquisa fotoetnográfica.

\section{A FOTOETNOGRAFIA NA OBJETIVA DA PESQUISA CIENTÍFICA}

O termo Fotoetnografia foi cunhado em $1996^{6}$ por Luiz Eduardo Robinson Achutti, ao defender sua dissertação de Mestrado em Antropologia Social na Universidade Federal do Rio Grande do Sul, intitulada “Fotoetnografia: um estudo de Antropologia visual sobre cotidiano, lixo e

\footnotetext{
${ }^{4}$ Para Sarmento (2005, p. 10) “o lugar da infância é um entre-lugar [...], o espaço intersticial entre os dois modos - o que é consignado pelos adultos e o que é reinventado nos mundos de vida das crianças” e neste espaço, elementos do passado e do futuro se comunicam.

${ }^{5}$ Bhabha (2013, p. 29) esclarece que o trabalho fronteiriço da cultura não apenas retoma o passado, reconfigurando-o como um "entre-lugar” contingente, que inova e interrompe a atuação do presente, mas torna-se parte e necessidade da própria vida.

${ }^{6}$ O ano de defesa de dissertação é 1996, mas o ano de publicação é 1997.
} 
trabalho". Achutti (1997, p. 12) utilizou uma abordagem descritiva, associada às técnicas antropológicas de pesquisa de campo, em que a imagem fotográfica foi sua principal forma de narrar, assim, buscou investigar os elementos com os quais a população construía seus traços identitários.

A Fotoetnografia, como perspectiva teórico-metodológica, permite não só examinar as narrativas imagéticas que compõem os discursos e as teorias que fundamentam e fundamentaram estudos e pesquisas científicas, como também, amplia as possibilidades de investigação empírica, tendo em vista seu potencial narrativo imagético para compreensão da realidade.

Com base no levantamento de literatura realizado junto aos repositórios digitais da CAPES, SciELO e ANPEd, a Fotoetnografia ainda é uma metodologia pouco explorada nas pesquisas científicas brasileiras, fato que nos levou a afirmar que, apesar da sua densidade epistemológica e empírica, ainda se trata de um campo em emergência que precisa ser ampliado e aprofundado nas Ciências Humanas e Sociais.

A partir do indexador “Fotoetnografia”, totalizam-se até o ano de 2017, 37 trabalhos, sendo, 8 teses, 18 dissertações e 11 artigos. Destas, 26 pesquisas foram registradas junto à CAPES desde 1996, porém, apenas 5 estão relacionadas, direta ou indiretamente, à crianças e infâncias, as quais forma lidas e selecionadas para análise.

Portanto, junto à CAPES foram selecionados 4 trabalhos, sendo, 1 dissertação em Antropologia (VILLAS BOAS, 2016); 1 dissertação em Dinâmicas Territoriais e Sociedade na Amazônia (MENEZES, 2016); 1 tese e 1 pesquisa em Educação (TROIS, 2012; SÁ, 2014). E junto à ANPEd apenas 1 recorte de pesquisa em andamento, que também foi analisado por abranger um estudo fotoetnográfico com crianças (APRATO, 2016). O quadro 2 apresenta a relação dos trabalhos que foram lidos na íntegra para análise e seleção de imagens.

\section{Quadro 2. Pesquisas selecionadas para análise fotoetnográfica}

\begin{tabular}{|c|c|c|c|}
\hline $\begin{array}{c}\text { Autor } \\
\text { (ano) }\end{array}$ & Título & $\begin{array}{c}\text { Tipo/Área } \\
\text { Instituição }\end{array}$ & Palavras-chave \\
\hline $\begin{array}{l}\text { TROIS } \\
\text { (2012) }\end{array}$ & $\begin{array}{l}\text { O privilégio de estar com } \\
\text { as crianças: o currículo } \\
\text { das infâncias. }\end{array}$ & $\begin{array}{l}\text { Tese. } \\
\text { Pós-Graduação em } \\
\text { Educação, UFGRS. }\end{array}$ & $\begin{array}{l}\text { Infância. Educação } \\
\text { Infantil. } \\
\text { Fotoetnografia } \\
\text { Currículo. Currículo } \\
\text { das Infâncias. }\end{array}$ \\
\hline $\begin{array}{l}\text { SÁ } \\
\text { (2014) }\end{array}$ & $\begin{array}{ll}\text { Saberes } & \text { Culturais } \\
\text { Tentehar e Educação } \\
\text { Escolar Indígena na } \\
\text { Aldeia Juçaral }\end{array}$ & $\begin{array}{l}\text { Dissertação. } \\
\text { Pós-Graduação em } \\
\text { Educação, UFPA. }\end{array}$ & $\begin{array}{l}\text { Educação Indígena. } \\
\text { Saberes culturais } \\
\text { Tentehar. } \\
\text { Saberes escolares. } \\
\text { Interculturalidade. }\end{array}$ \\
\hline
\end{tabular}




\begin{tabular}{|c|c|c|c|}
\hline $\begin{array}{l}\text { VILLAS } \\
\text { BOAS } \\
(2016)\end{array}$ & $\begin{array}{l}\{\text { Per[for(mar)]\} Imagens } \\
\text { das crianças no Nêgo } \\
\text { Fugido, Acupe/B. }\end{array}$ & $\begin{array}{l}\text { Dissertação. } \\
\text { Pós-Graduação em } \\
\text { Antropologia Social, } \\
\text { UnB. }\end{array}$ & $\begin{array}{l}\text { Criança. Performance. } \\
\text { Cultura Popular. } \\
\text { Recôncavo Baiano. }\end{array}$ \\
\hline $\begin{array}{l}\text { APRATO } \\
\text { (2016) }\end{array}$ & $\begin{array}{l}\text { Crianças e objetos: } \\
\text { Narrativas } \\
\text { fotoetnográficas } \\
\text { infâncias contemporâneas }\end{array}$ & $\begin{array}{l}\text { Recorte de Dissertação } \\
\text { em andamento na } \\
\text { Universidade Luterana } \\
\text { do Brasil, ULBRA, } \\
\text { apresentado no XI } \\
\text { Seminário de Pesquisa } \\
\text { em Educação da } \\
\text { Região Sul, ANPEd } \\
\text { SUL. }\end{array}$ & $\begin{array}{l}\text { Não apresenta } \\
\text { palavras-chave em seu } \\
\text { escopo, mas, se trata } \\
\text { de pesquisa com } \\
\text { criança no contexto } \\
\text { escolar. }\end{array}$ \\
\hline $\begin{array}{l}\text { MENEZES } \\
\text { (2016) }\end{array}$ & $\begin{array}{l}\text { Cultura Indígena Híbrida: } \\
\text { uma abordagem } \\
\text { interdisciplinar } \\
\text { Pintura acerca da } \\
\text { Parketêjê. }\end{array}$ & $\begin{array}{l}\text { Dissertação. } \\
\text { Pós-Graduação em } \\
\text { Dinâmicas Territoriais } \\
\text { e Sociedade da } \\
\text { Amazônia, } \\
\text { UNIFESSPA. }\end{array}$ & $\begin{array}{l}\text { Cultura estética } \\
\text { indígena. } \\
\text { Hibridismo cultural } \\
\text { indígena. Pintura } \\
\text { corporal } \\
\text { Parketêjê. }\end{array}$ \\
\hline
\end{tabular}

Fonte: Elaboração própria (2018).

A tese de Trois (2012) ${ }^{7}$ é o primeiro trabalho em Educação Infantil que utiliza a Fotoetnografia como estratégia metodológica para pesquisas com crianças no Brasil. Teve o objetivo de refletir, compreender e interrogar sobre como acontece a participação das crianças na escola e quais as marcas que registram e produzem o currículo da infância, sendo realizada em uma escola infantil da rede municipal de Porto Alegre. Evidencia a importância da fotografia como narrativa visual que ajuda a ver, registrar e pensar as infâncias e suas pluralidades, pois, para a autora, “Toda fotografia é um olhar sobre o mundo, levado pela intencionalidade de uma pessoa procurando dar significado a este mundo” (TROIS, 2012, p. 35). A autora conclui que o currículo da infância é atravessado pela emergência de uma "infância plural que pulsa, que vibra, que silencia, que interroga e que, sobretudo, age” (TROIS, 2012, p. 161).

A pesquisa fotoetnográfica de Villas Boas $(2016)^{8}$ é um trabalho de cunho etnográfico que trata da construção de si das crianças que participam da manifestação popular “Nêgo Fugido” em uma pequena vila chamada Acupe, no distrito de Santo Amaro, localizado no Recôncavo Baiano.

\footnotetext{
${ }^{7}$ QRcode 14: Trois (2012).

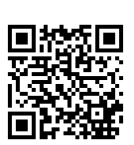

${ }^{8}$ QRcode 15: Villas Boas (2016).
} 
Trata-se de um evento cultural em que adultos e crianças encenam a história de luta pela libertação escrava durante todos os domingos do mês de julho. Villas Boas (2016) buscou investigar como as crianças vivenciam suas infâncias localmente, como constroem suas relações entre pares e intergeracionais e como performatizam essa manifestação cultural formando a si mesmas nessa conjuntura.

Aprato (2016) apresenta um recorte de pesquisa de mestrado que está sendo realizada com foco nas culturas infantis. O artigo aborda de forma sucinta, três narrativas fotoetnográficas produzidas junto a crianças que frequentam o $1^{\circ}, 2^{\circ}$ e $3^{\circ}$ ano do Ensino Fundamental da Escola Estadual Fortaleza em Rio Pardo, no interior do Rio Grande do Sul. Os objetivos desta pesquisa caminham em direção à construção de narrativas que representem a relação contemporânea entre crianças e objetos relacionada a espaços intra e extraescolares, fartamente explorados nas representações imagéticas sobre a infância através dos tempos, dando ênfase às questões do consumo na produção das infâncias pós-modernas. A pesquisa de Aprato revela que as questões do consumo na infância repercutem de forma incisiva na relação das crianças com os objetos que as conectam com seu tempo, gerando consequências nas relações interpessoais e sociais que estabelecem entre si e com o outro no contexto escolar e doméstico (APRATO, 2016, p. 10-11) ${ }^{9}$.

O trabalho de dissertação de Menezes $(2016)^{10}$ teve o objetivo de apontar as dimensões das fronteiras culturais entre cultura indígena e cultura não indígena que se entrelaçam na tradição da pintura corporal "Parkatêjê", ressaltando as narrativas que definiram por muito tempo e ainda continuam a influenciar, a imagem estereotipada dos “índios do Brasil”. Para tanto, a autora mergulha no universo cultural dos “Gaviões Parketêjê” para conhecer os costumes, crenças, tradições familiares que estão estampadas nas pinturas corporais que atravessam gerações. As imagens presentes no estudo revelam cenas do cotidiano social, das paisagens naturais, das expressões estéticas da pintura corporal e suas representações culturais e ideológicas. Trata-se de uma pesquisa que desvela imagens de crianças que exercem seu protagonismo em busca da

\footnotetext{
${ }^{9}$ QRcode 22: Aprato (2016).

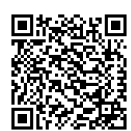

${ }^{10}$ QRcode 23: Menezes (2016).
} 
felicidade que está na liberdade de viver na floresta, a floresta que encanta o imaginário infantil através de tantos contos e fábulas.

Nesta mesma vertente empírica, a dissertação de Sá (2014) teve o objetivo de analisar como ocorre o diálogo intercultural entre saberes e práticas culturais “Tentehar” e os saberes escolares (técnicos/ científicos) na escola da aldeia Juçara. A pesquisa apresenta um acervo fotográfico diversificado que revela cenas do cotidiano da aldeia, seus costumes e tradições que estão presentes nas práticas socioeducativas que compõem o núcleo diversificado do currículo da escola indígena Santarena Kapi. De acordo com os achados da pesquisa, apesar da escola ter sido criada como um espaço de fortalecimento da cultura local onde as disciplinas são trabalhadas com o objetivo de contribuir para o fortalecimento dos saberes culturais locais e valorização da língua “Tentehar”, ainda persistem práticas descontextualizadas e colonizadoras. A imagens de crianças nesta pesquisa buscam contrapor as realidades culturais da infância vivida na aldeia, ora as crianças são corresponsáveis pelas tarefas domésticas, ora estão livres na natureza exercendo seu protagonismo e criatividade no brincar.

Em síntese, a Fotoetnografia, se mostra um campo fecundo para o re/conhecimento das crianças, seus lugares, seus modos de vida, suas subjetividades e culturas. Na sequência, apresento a construção metodológica na qual se constituiu a pesquisa fotoetnográfica de carácter autobiográfico.

\section{A FOTOETNOGRAFIA AUTOBIOGRÁFICA NA PESQUISA COM CRIANÇA}

A fotoetnografia de inspiração autobiográfica busca um diálogo entre epistemologias e metodologias que caminham em direção ao desvelamento da realidade da infância a partir da óptica da própria criança, marcando assim, posição na defesa de sua participação na pesquisa, consequentemente, rompendo com sua in/visibilidade científica.

O percurso metodológico se delineia em procedimentos não convencionais que potencializaram as relações entre pesquisador e sujeito-infantil, reconhecendo a complexidade das infâncias a partir das singularidades dos modos de ser da criança, aproximando-se dessa maneira, das culturas que se produzem não só através de processos reprodutivos, mas sim, processos que são construídos de modo recursivo na reprodução social (GIDDENS, 1984, p. XXV), processos estes, que fundamentam a teoria da reprodução interpretativa de Corsaro (1993, p. 114), também entendida no contexto das pesquisas em Sociologia da Infância como uma forma de "apreensão 
criativa” da criança (MÜLLER; CARVALHO, 2009, p. 23; MARTINS FILHO; PRADO, 2011, p. 3).

Desse modo, para organização das narrativas fotoetnográficas, traçamos os seguintes procedimentos: seleção de fotografias impressas dispostas nos álbuns de família; seleção de fotografias digitais disponíveis em computadores da família e redes sociais; análise qualitativa das imagens selecionadas; organização da narrativa fotoetnográfica a partir da percepção da própria criança. Todos esses procedimentos privilegiaram a escuta da criança.

Para análises dos resultados direcionamos o olhar para o desvelamento das culturas da infância procurando identificar evidências de protagonismo infantil. Em outras palavras, consideramos, prioritariamente, as percepções ontológicas e interpretativas da própria criança acerca de sua história de vida, buscando perceber suas próprias percepções acerca do que é ser criança e ter uma infância. Neste sentido, o método fotoetnográfico empreendido aqui, adquiriu outras dimensões na pesquisa empírica, tendo em vista que, agora, seu objeto passou a ser narrado e interpretado pelo próprio sujeito de sua narrativa - a criança. Daí a necessidade de fazermos algumas implementações ao método, porém, não desconsiderando suas premissas epistemológicas e metodológicas. Com vistas a tais argumentos, a narrativa fotoetnográfica autobiográfica abrangeu, basicamente, duas dimensões, ambas implicadas no movimento cíclico de interpretação.

A primeira refere-se à percepção do sujeito investigado (criança-sujeito) - à medida que a criança produz a narrativa visual autobiográfica e elabora sua compreensão num processo de reflexão interpretativa dos fatos (CORSARO, 1997), dando sentidos e significados às suas experiências visuais e sensitivas.

A segunda refere-se à percepção da pesquisadora- durante o processo de geração de dados junto à criança-sujeito, através de diário fotoetnográfico e durante o processo de análise interpretativa (GRAUE; WALSH, 2003, p. 33-39) das narrativas fotoetnográficas produzidas pela criança-sujeito à luz das concepções teóricas que pautaram as investigações.

Deste modo, as Fotoetnografias tomaram formas distintas, porém, complementares. Requereram para si, efeitos de veracidade e de subjetividade construídos de formas híbridas e transversais, sobretudo, reais e éticas.

Produzir uma Fotoetnografia narrada e organizada sob o ponto de vista infantil, desde a seleção de imagens até a descrição narrativa dos signos e significados relativos à sua história de vida, não foi uma tarefa fácil. Rocha e Passeggi (2012, p. 115) ao tratar da narrativa autobiográfica ressaltam que essa modalidade parte de princípios epistemológicos que proporcionam a apropriação 
de histórias e memórias, constituindo-se uma forma de empoderamento ${ }^{11}$. As autoras também destacam que a escuta sensível do Outro, parte do reconhecimento de sua história de seu pertencimento social, desse modo, na pesquisa autobiográfica, “os processos reflexivos e de ressignificação das experiências são importantes, tanto para a pessoa que narra, quanto para quem às escuta, incluindo o pesquisador, que se forma com a pesquisa e com quem dela participa (ROCHA; PASSEGGI, 2012, p. 115).

Portanto, a fotografia tornou-se um “elemento detonador de outras memórias" (CARVALHO, 2011, p. 118), ou seja, através da fotografia, o real é evocado e revelado, tornandose um critério de verdade (KOURY, 1998, p. 74). Nesse sentido, diante da fotografia, a criançasujeito pôde reviver seu passado-presente, contemplar o belo e compreender a plenitude da sua própria infância.

\section{CANTOS, CONTOS E ENCANTOS DE MARIA CLARA - A PRINCESA "BLOGUEIRINHA"}

Cantos, contos e encantos embalaram esta pesquisa. A princesa Maria Clara deixou registrada sua história - “Uma História de amor, de aventura e de magia”. Seu reino encantado é muito agitado, mas essa também é uma de suas principais características, ela não para! Está sempre aprontando todas e não para de falar! Por isso, não foi necessário muito esforço para realização desta pesquisa, justamente, pelo seu jeitinho alegre e expressivo de se relacionar e se expressar.Para Clara, a vida é uma “magnífica aventura” aonde ela vai desenhando suas histórias com muita autenticidade.

Maria Clara vive os encantamentos de uma infância repleta de criatividades e imaginações, ora é uma princesa, que cria seus próprios contos de fadas, ora é uma "blogueirinha” que sonha em ser artista de TV, apresentadora ou uma “atriz contratada”, sonha também em ser modelo para “desfilar nas passarelas do mundo inteiro”, mas não para por aí, quer também ser cantora ou dançarina, mas, se isso tudo não acontecer ou quando isso tudo acabar, aí ela disse que vai ser veterinária para “cuidar dos bichinhos que ficam dodói”, pois Clara ama os animais. Realmente, essa pequena tem muita história para contar.

A família materna de Maria Clara morava no interior da Paraíba e quase não vinha para João Pessoa, em vista disso, em 2013, sua mãe criou um perfil no Facebook - “@neyangelafreitas” e um

\footnotetext{
11 O empoderamento para Rocha e Passeggi (2012, p. 115) é entendido na perspectiva de que as narrativas autobiográficas se originam a partir do conhecimento de si, ou seja, da apropriação do sujeito em relação à sua própria história e pertencimento social.
} 
instablognoInstagran - “@achadinhosdemariaclara”, com a intenção de divulgar suas imagensapenas para a própria família, mas, manteve raras publicações.

Apenas a partir de 2016, sua mãe passou a postar com certa frequência imagens e vídeos de Maria Clara no Instagram. Seu primeiro vídeo datado em 20 de fevereiro de 2016 mostra Clara com 5 anos apresentando uma roupa que foi customizada por ela com a ajuda de sua mãe, daí em diante as postagens ficaram cada vez mais frequentes, passando com isso, a se denominar de “blogueirinha”.Nas palavras de Clara, “blogueirinha” é uma pessoa que: “faz vídeos para Internet sobre moda, sobre ser criança, sobre as coisas que a pessoa faz, e também, éeee... sobre coisas que a gente pode fazer como dicas de pintura, lembrancinhas para o papai, muita coisa assim [...]”. Atualmente, Clara possui 5.265 seguidores no Instagram, faz postagens sobre moda, festas, promoções comerciais, festividades escolares, datas comemorativas, entre outras, porém, não tem vínculo comercial com nenhuma empresa. Também participa de eventos de moda, desfiles e faz participações em programas locais de televisão.

Dada as limitações destas laudas, apresentamos a seguir um pequeno excerto da fala de Maria Clara que representa suas percepções acerca do que é ser criança e do que é a infância, objetos de análise deste artigo:

Pesquisadora (P) - Na sua opinião o que é ser criança? MC: Criança... é... [ficou pensativa]. Maria Clara (MC) - alguns pais querem que as crianças sejam sérias, bem chique sabe? mas criança é brincar, se divertir, as crianças são do jeito que elas são, mas os pais querem fazer uma orientação que querem que a criança fique grande, alguns, e não querem que elas sejam uma criança, porque é uma criança séria que fica. P: Entendi, e na sua opinião ser criança é ser...? [insisti]. MC: Criança, é brincar, se divertir, eu sei que é meio doido a gente fazer algumas coisas erradas, mas a gente gosta, faz parte do nosso dia-dia. P: Entendi, e o que é coisa errada assim? MC: Eu gosto de ficar pegando algumas coisas da minha mãe enganando ela, e quando minha mãe vai me dar um abraço eu tento pegar o celular dela e aí eu corro e coloco o celular na minha frente, só que aí ela pega no flagra e eu também gosto de trocar coisas.

P:Você falou o que é ser criança, mas você sabe o que é a infância?MC: Infância é quando a gente era pequeno, sabe? Ser bebê, ser criança, aí a gente vai crescendo até virar um adulto, o adulto aí sim pode ser sério, mas eu ainda gosto de me divertir mesmo sendo adulta, não tem problema. P: Aí no caso, você é uma pessoa bem alegre. MC: Sou. P: Você é feliz? MC: Sou.

P: E qual a melhor parte de ser criança?MC: A melhor parte é que a gente tem que aproveitar as nossas brincadeiras, nossas aventuras, nossas amizades, o tempo livre da 
gente, pois quando a gente for adulto vai ter que ficar ocupado e eu não gosto muito, por isso tenho que aproveitar por enquanto que sou criança. P: E o que você diria pra um adulto? Pra ele entender o que é ser criança? MC: Eu diria que ser criança é ter liberdade de brincar, mesmo a criança fazendo alguma coisa, ter quebrado alguma coisa ou se machucado, faz parte do nosso dia-dia. A gente pode se machucar? Pode, mas a gente não se cansa de brincar, a gente quer conseguir as coisas, principalmente, um menino que sonhava fazer skate, mas ele não tinha as pernas, mas aí ele fez todos quererem, mesmo ele não tendo pernas, porém ele conseguiu, ele só usa as mãos. P: É só acreditar né? MC: Uhum, pra seu sonho se realizar.

Maria Clara constrói sua história de forma participativa e ativa. É uma criança que sabe questionar, criticar, refletir e ter suas próprias opiniões. Essa autonomia, desvela uma criança protagonista que quer participar de todas as decisões relacionadas a ela. As falas de Clara demonstram empoderamento do que é ser criança e de saber o que é viver com dignidade a sua infância. Essa visão é defendida pela Sociologia da Infância por acreditar na autonomia do pensamento infantil eno protagonismo desvelado nos seus modos de ser e de viver na atual sociedade.

Na óptica da Sociologia da Infância, reconhecemos em Clara e em outras tantas Claras, a imagem da criança protagonista,que constrói suas culturas e estabelece sentidos e significados nas relações entre pares e com os adultos de maneira proativa e criativa, que se reconhece como criança e conquista seus direitos de infância.

Portanto, convidamos o leitor a se encantare sentir as emoções e singularidades do ser criança através das aventuras da princesa "blogueirinha” Maria Clara, narradas e produzidas pela protagonista desta história, e, por nós, transformada em narrativa fotoetnográfica. 


\section{“OI PESSOAAAL! EU SOU A BLOGUEIRINHA MARIA CLARA!”: POR UMA FOTOETNOGRAFIA AUTOBIOGRÁFICA}

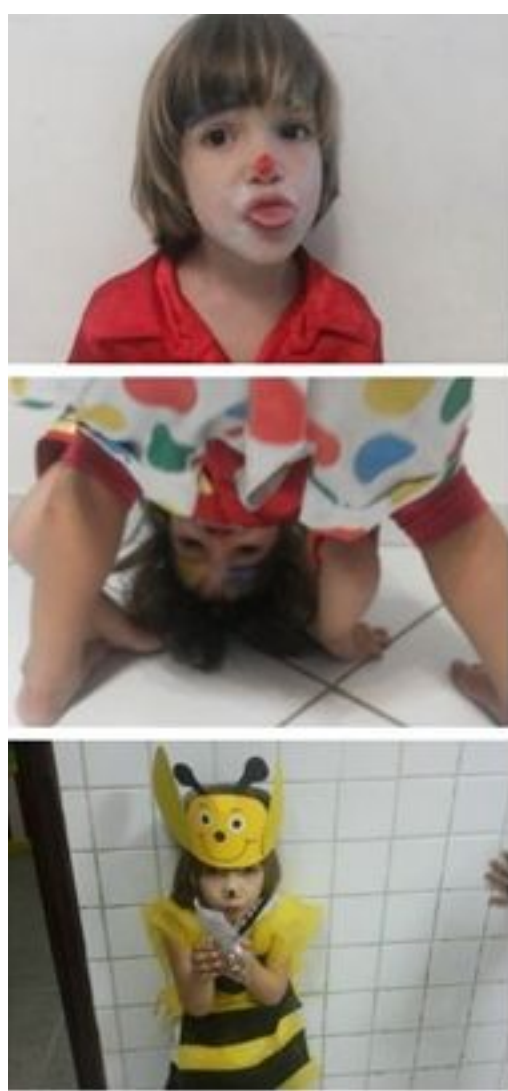

$\mathbf{1}$
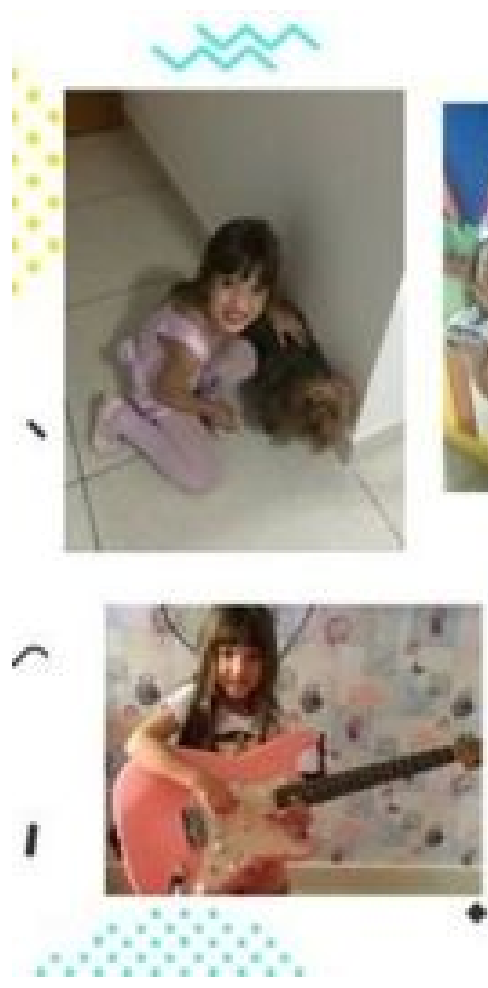
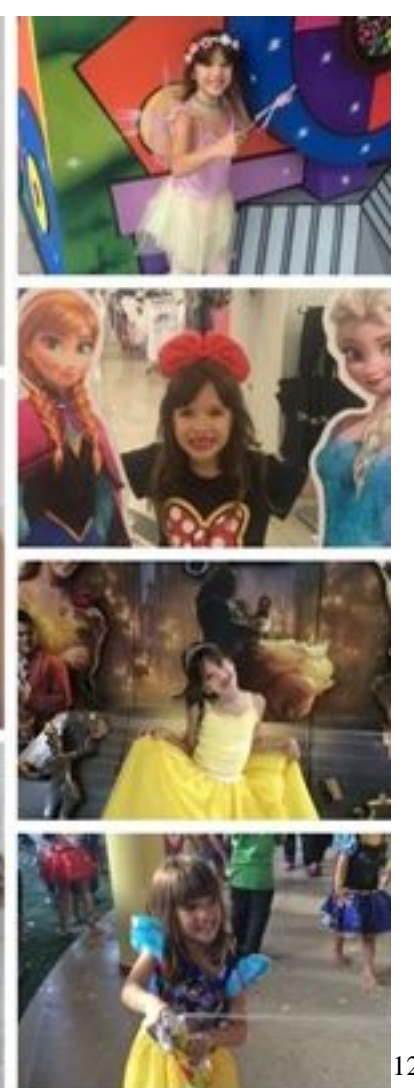

12
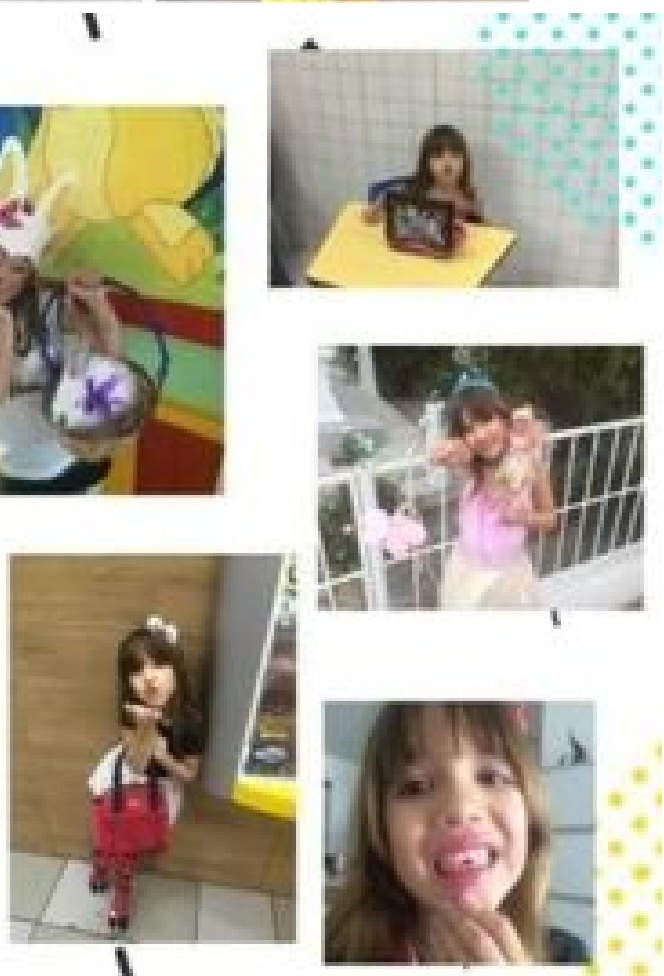

tin
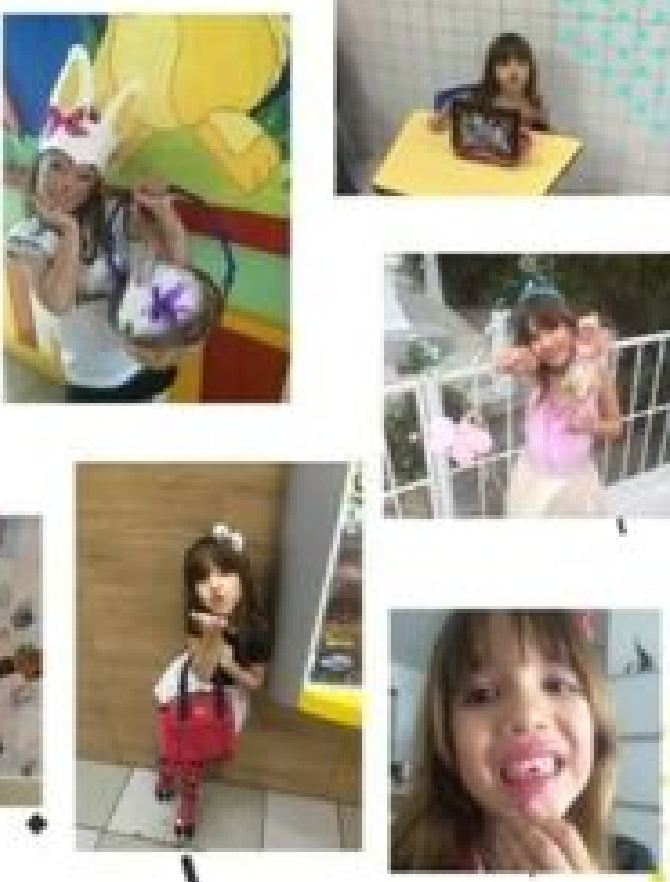

13

\footnotetext{
${ }^{12}$ Mosaico 1: Fotografias do acervo familiar, para mostrar suas fantasias de carnaval (06/2017).

${ }^{13}$ Mosaico 2: Fotografias do acervo familiar, escolhidas para mostrar animais preferidos, brinquedos e o momento em que ela perdeu um dentinho (06/2017).
} 

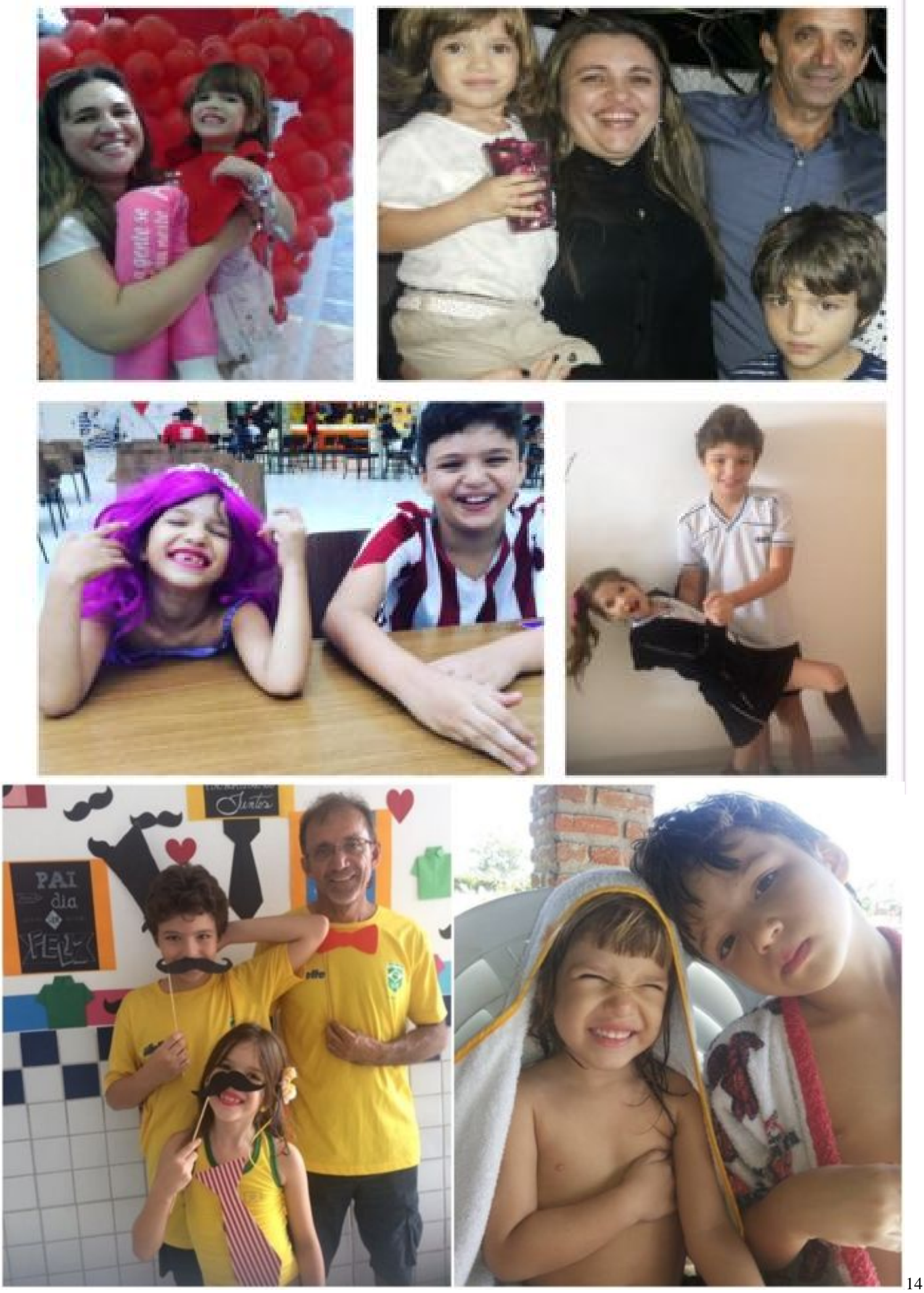

${ }^{14}$ Mosaico 3: Fotografias do acervo familiar que desvelam os momentos em família (07/2017). 


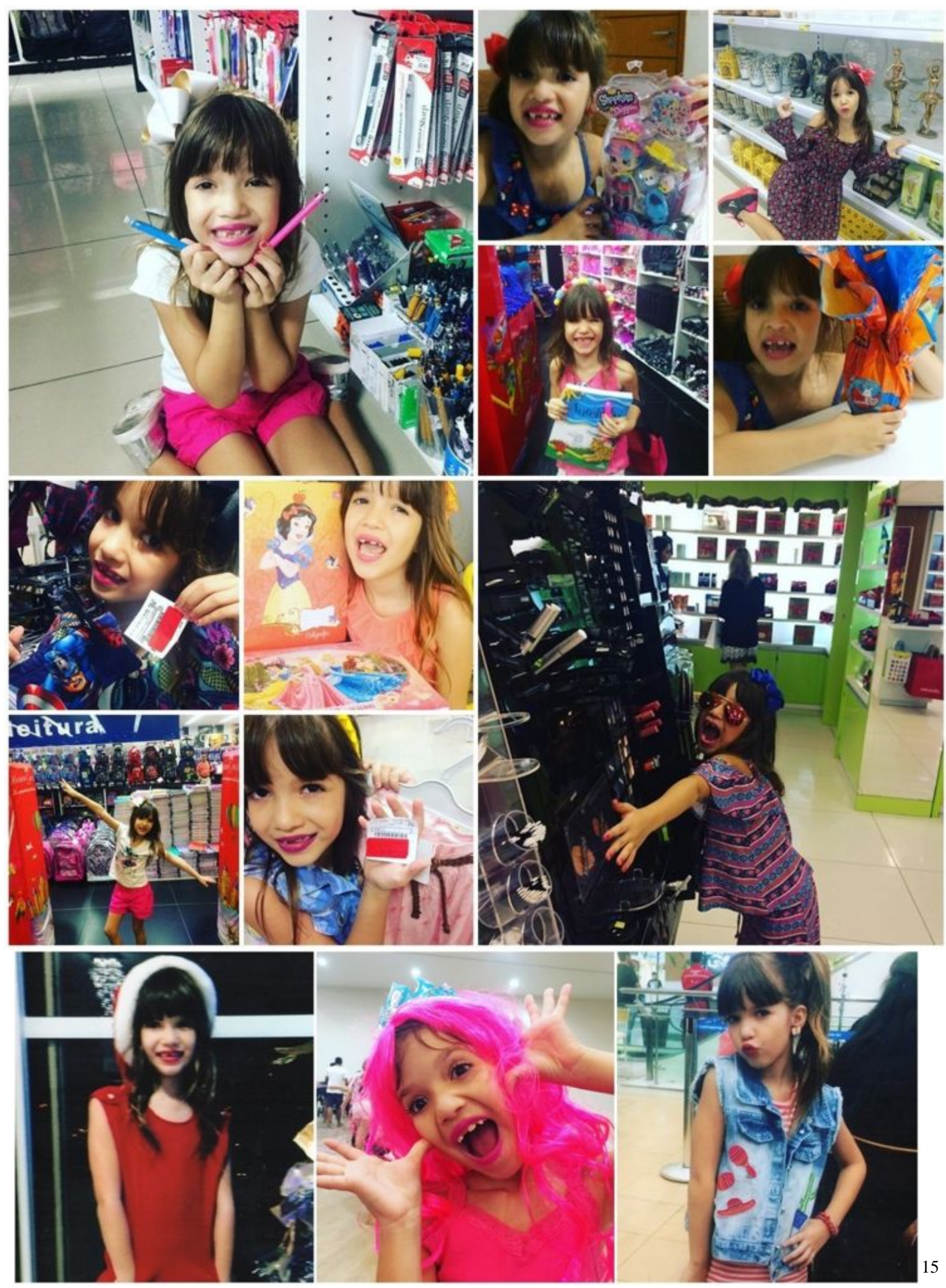

\footnotetext{
${ }^{15}$ Mosaico 4: Imagens retiradas do instablog “@achadinhosdemariaclara” (072017).
} 


\section{MARIA CLARA OLIVEIRA 7 \\ MARIA CLARA ENSINA \\ ANOS NOS MOSTRA COMO PASSO A PASSO PARA \\ FAZER UM PRATO JUNINO \\ SUPER RÁPIDO E PRATICO VOCÊ ARRASAR NO SÃO JOÃO}

MARIA CLARA DÁ DICAS DE LOOKS PARA AS CRIANÇAS
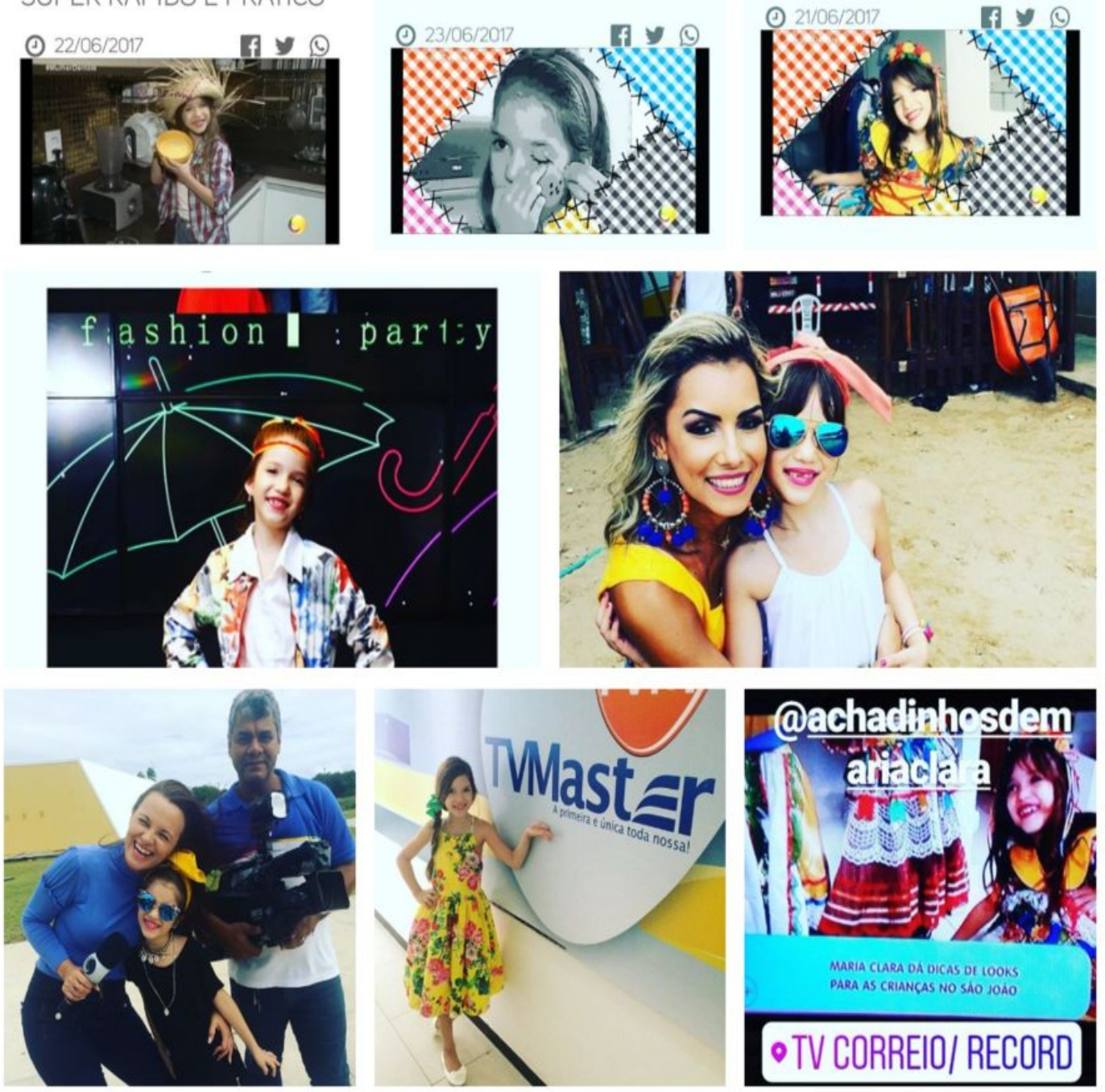

16

\footnotetext{
${ }^{16}$ Mosaico 5: Imagens retiradas do instablog “@achadinhosdemariaclara”. Participações em programas de TV local. (06-07/2017).
} 


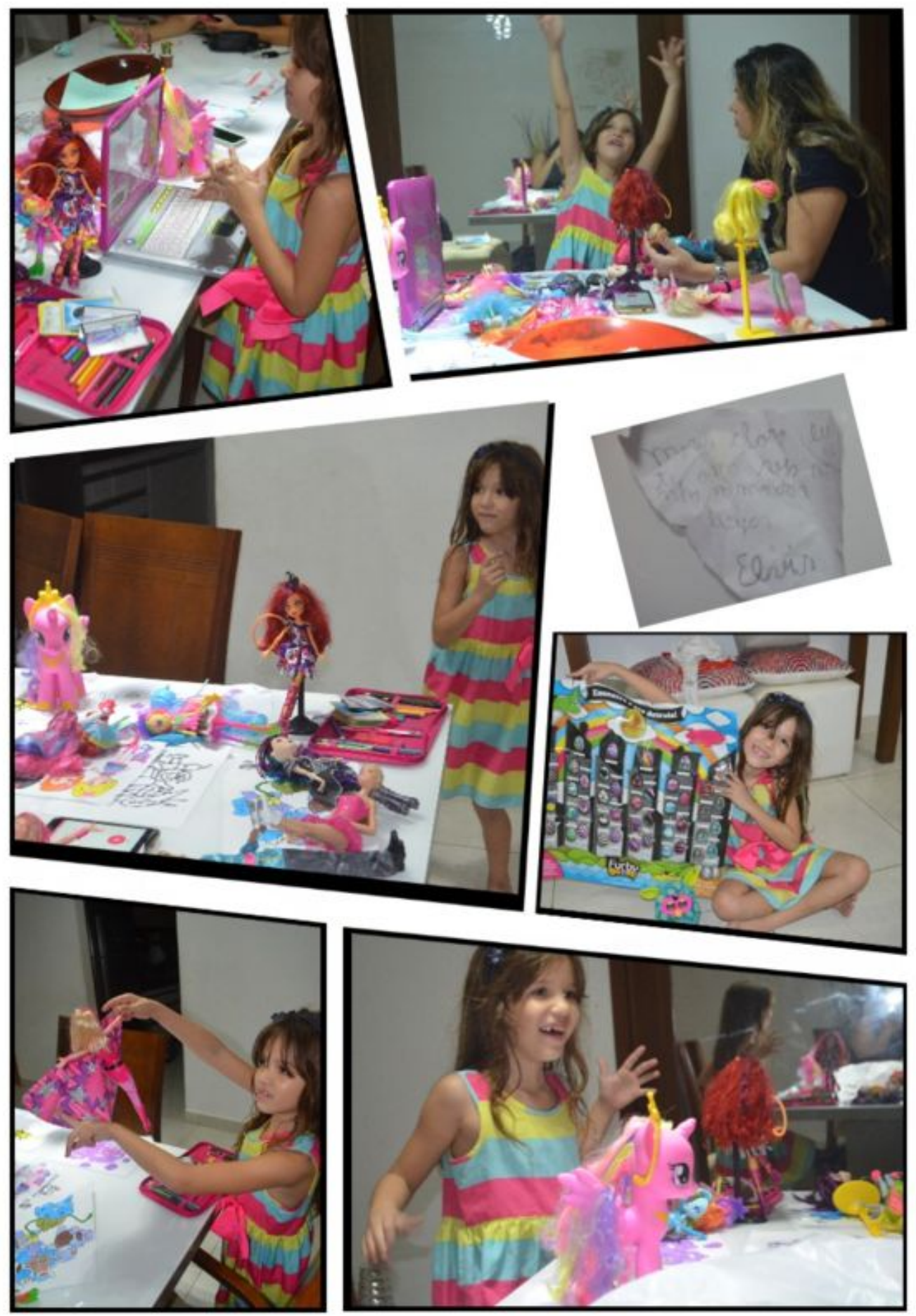

\footnotetext{
${ }^{17}$ Mosaico 6: Fotografias produzidas na residência da criança-sujeito durante pesquisa fotoetnográfica. Maria Clara mostra seus brinquedos e conta suas aventuras (04-07/2017).
} 


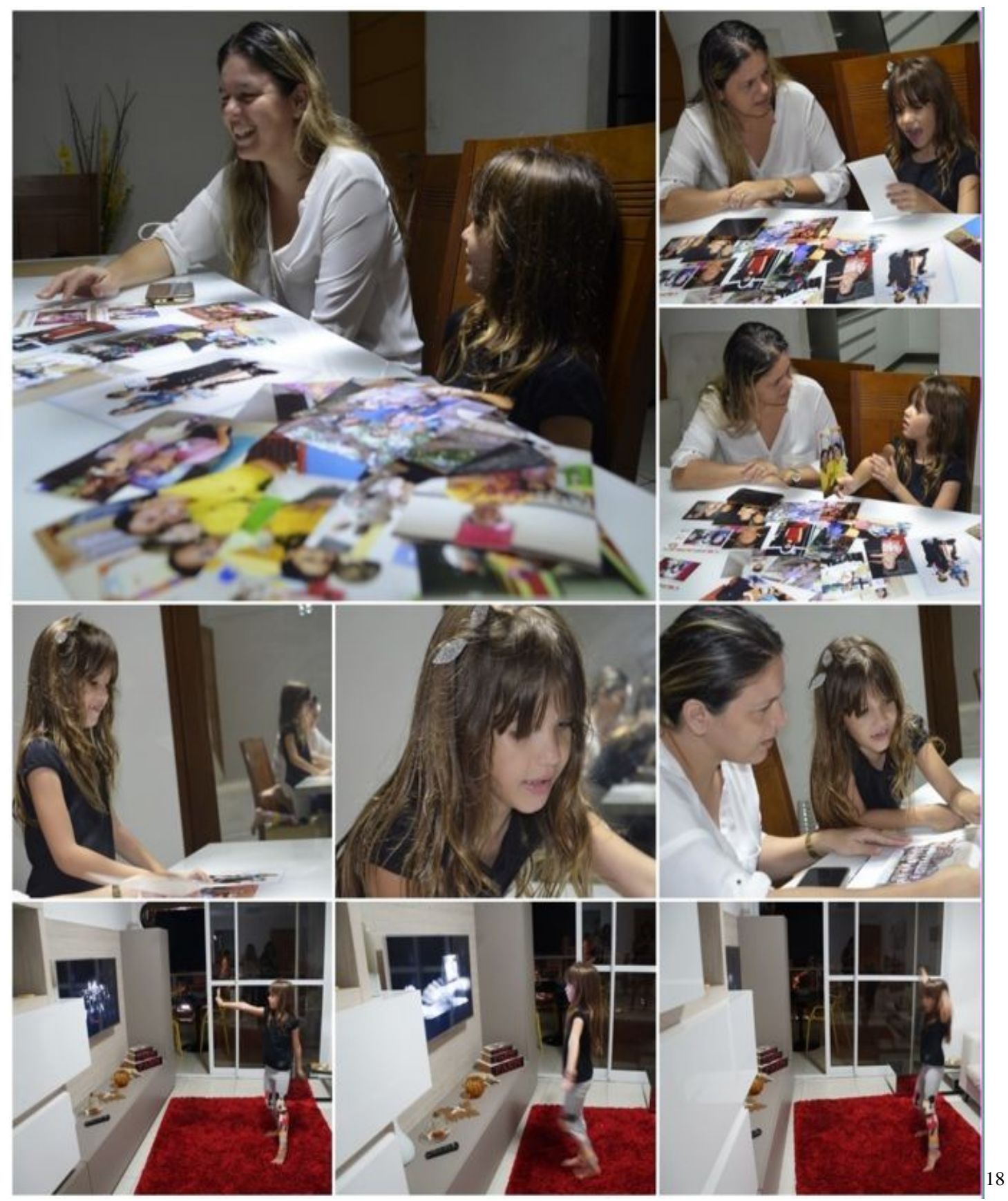

\footnotetext{
${ }^{18}$ Mosaico 7: Fotografias produzidas por uma auxiliar de pesquisa durante a seleção de imagens. Maria Clara analisa, descreve e escolhe as fotografias que contam a história de sua vida e faz uma performance ao som da música "Prepara" da cantora Anitta (04-07/2017).
} 

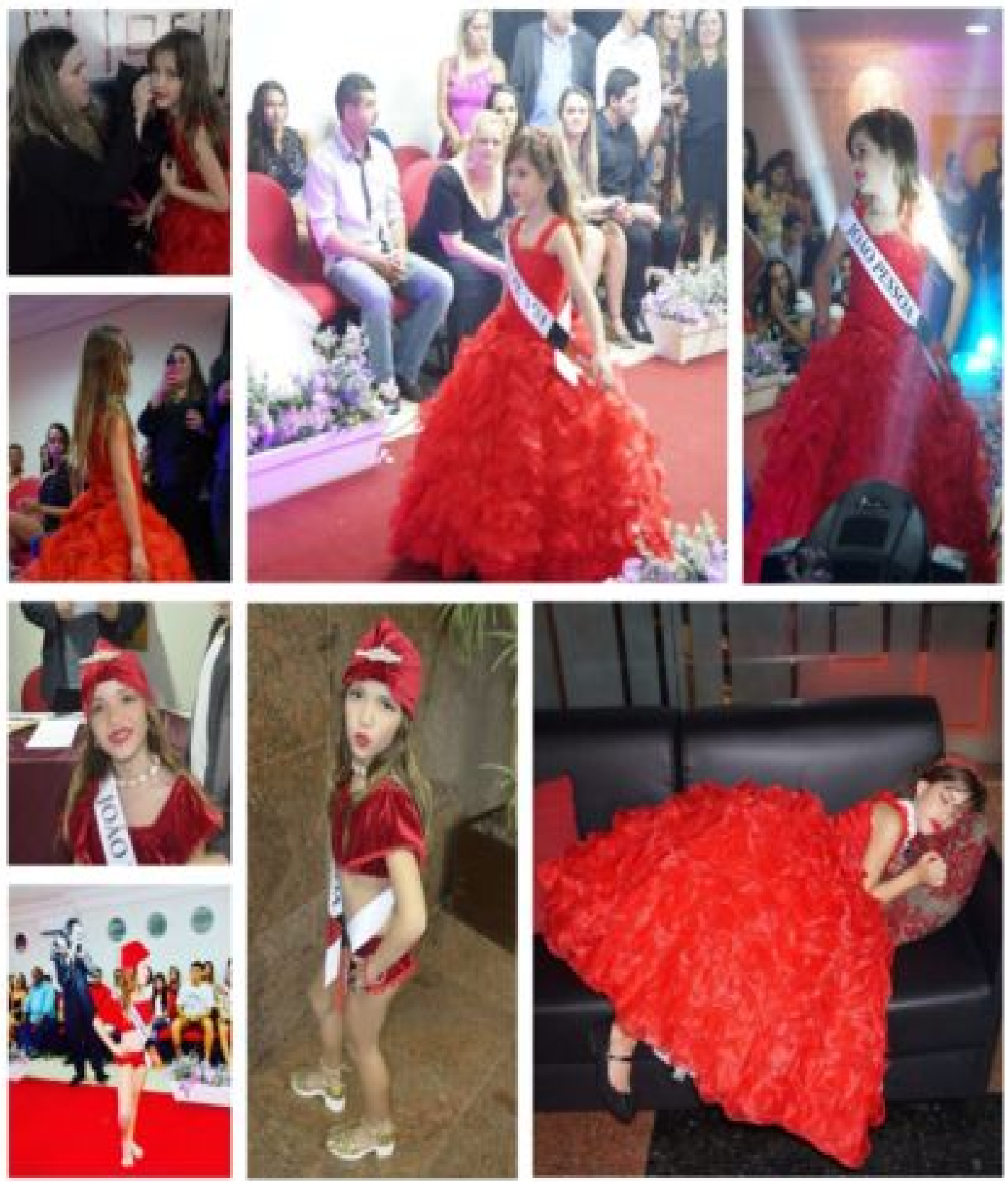

19

\footnotetext{
${ }^{19}$ Mosaico 8: Fotografias produzidas durante pesquisa fotoetnográfica. Maria Clara participa de um concurso de beleza infantil (06/2017).
} 

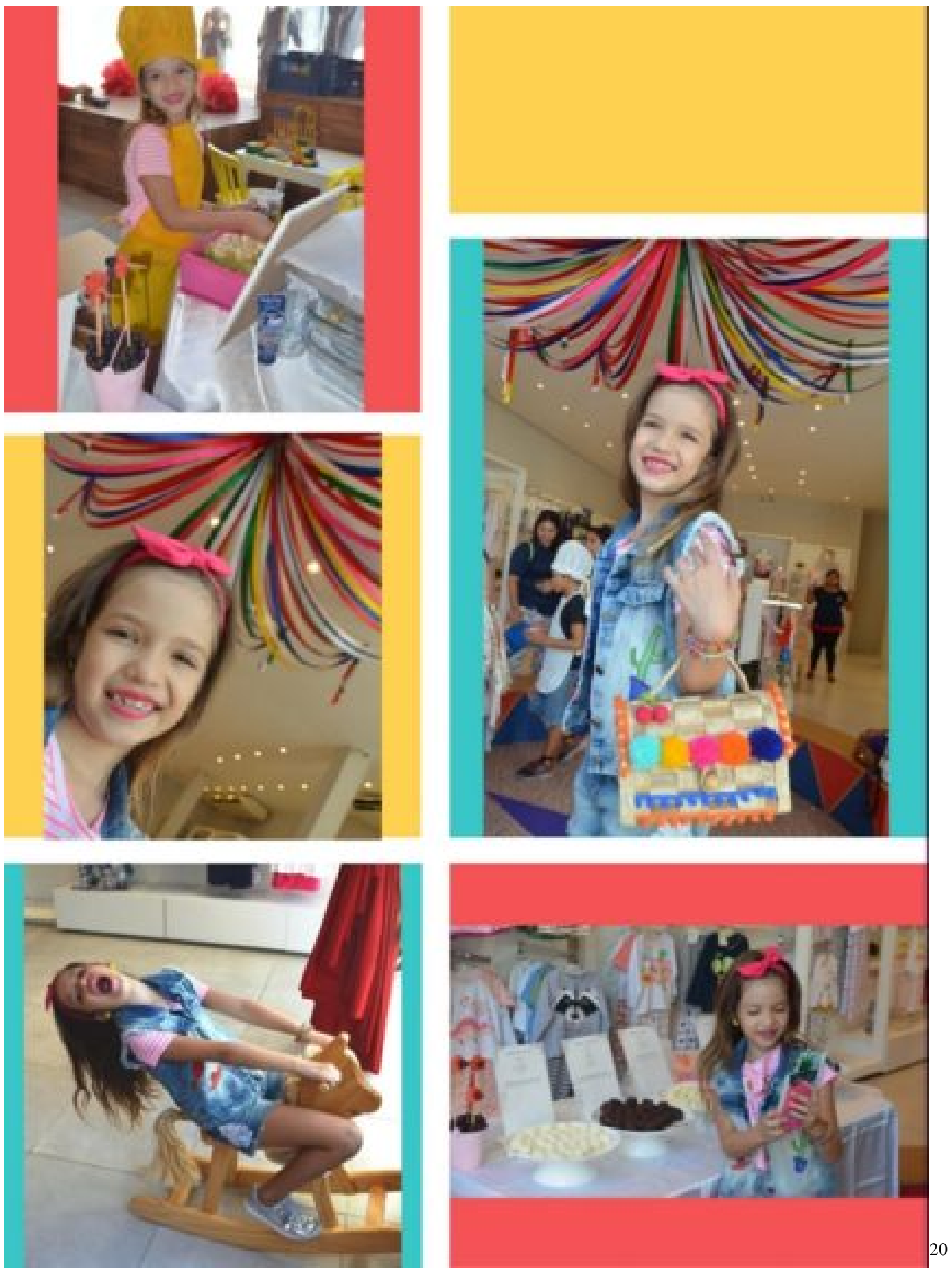

\footnotetext{
${ }^{20}$ Mosaico 9: Fotografias produzidas durante pesquisa fotoetnográfica. Maria Clara participa de evento infantil em loja de roupas, brinca, degusta brigadeiros saudáveis e grava um vídeo para seu instablog (06/2017).
} 


\section{CONSIDERAÇÕES FINAIS}

A produção de narrativas fotoetnográficas permitiu o conhecimento, aprofundamento e desvelamento interpretativo das concepções de crianças e infâncias refletida nas imagens de crianças discutidas pela História Social da criança e pela Sociologia da Infância. Legitimando-se, assim, como uma nova estratégia de aproximação, reflexão e análise teórica e empírica para o desenvolvimento de pesquisas direcionadas às temáticas crianças, infâncias e culturas infantis nas Ciências Humanas e Sociais, tendo em vista sua potencialidade metodológica para estimular a interpretação e compreensão das identidades, subjetividades e alteridades da criança produzidas nos entre-lugares e entre-culturas da infância.

As narrativas fotoetnográficas reforçam a ideia de que as crianças exercem papéis sociais de acordo com as concepções de infância intensificadas pelas culturas, pelos discursos sociais e padrões culturais que tentam subsumir a criança a uma condição reducionista de direitos e participação. Entretanto, desde a posição de marginalidade e invisibilidade até a condição de sujeito social na contemporaneidade, é possível perceber que as crianças têm demonstrado em suas culturas extratos de subversão e resistência às concepções adultizadas de infância impostas pela história, pela sociedade e pela cultura, fazendo emergir assim, suas subjetividades e identidades através do protagonismo infantil, agora ainda mais reforçado por iniciativas sociais, políticas e educativas.

Sob a ótica da Sociologia da Infância reiteramos que as crianças interpretam seus mundos e modos de viver a vida nas múltiplas interações simbólicas estabelecidas entre si e com os adultos, num exercício contínuo de alteridade. À medida que internaliza e interpreta os processos sociais que vivencia, ela nos interpela com suas re/formulações e nos desafia a entender o universo infantil a partir de seu próprio olhar e não do modo de como a vemos e/ou pensamos (CORSARO, 1997; SARMENTO, 2007; MÜLLER; CARVALHO, 2009; DORNELLES, 2005).

Desse modo, independentemente das circunstâncias e contextos, as crianças exercem seu protagonismo nas relações de alteridade constituídas durante a infância e constroem, criativamente, formas próprias de subversão e enfrentamento das circunstâncias culturais e sociais das quais participa, o que consiste numa nova imagem sociológica na contemporaneidade - a da criança protagonista. 


\section{REFERÊNCIAS}

ABRAMOVICZ, Anete e OLIVEIRA, Juliana. A sociologia da Infância no Brasil: uma área em construção. In: Revista do Centro de Educação da UFSM. Dossiê: Infância e educação infantil. Jan/abril.2010, v.35, nº1.

ACHUTTI, Luiz Eduardo Robinson. Fotoetnografia: Um estudo de Antropologia Visual sobre cotidiano, lixo e trabalho. Livraria Palmarinca. Tomo. Editorial Porto Alegre. 1997.

Fotoetnografia da Biblioteca Jardim. Porto Alegre: Tomo Editorial, 2004.

APRATO, Ana Paula Lima. Crianças e Objetos: narrativas fotoetnográficas sobre infâncias contemporâneas. In: REUNIÃO CIENTÍFICA REGIONAL DA ANPED, XI. Anais... Paraná: UFPR, 2016. Disponível em: <http://www.anpedsul2016.ufpr.br/trabalhos-completos-eixo-10-ensino-fundamental/>. Acesso em: 10 fev. 2017.

BHABHA, Homi K. O local da cultura. Trad.: Myrian Ávila, Eliana Lourenço de Lima Reis, Glaucia Ramos Gonçalves. 2. ed. Belo Horizonte: Ed. UFMG, 2013.

CARVALHO, César Augusto de. Os usos de fotografias de família. In: PEIXOTO, Clarice. Antropologia e Imagens, vol. 1: narrativas diversas (org.). Rio de Janeiro: Garamond, 2011. (p. 109-144).

CORSARO, William Arnold. Reproduction in Children's Role Play. Childhood, 1, p. 64-74.1993.

The Sociology of Childhood. California: Pine Forge Press, 1997.

DORNELLES, Leni Vieira. Infâncias que nos escapam: da criança na rua à criança cyber. Petrópolis: Vozes, 2005.

FERNANDES, Florestan. As Trocinhas do Bom Retiro: contribuição ao estudo folclórico e sociológico dos grupos infantis. In: FERNANDES, Florestan. Folclore e mudança social na cidade de São Paulo. 2. ed. Petrópolis/RJ: Vozes, 1979.

GIDDENS, Anthony. A constituição da sociedade. São Paulo: Martins Fontes, 1984.

GRAUE, M. Elizabeth; WALSH, Daniel J. Investigação etnográfica com crianças: teorias, métodos e ética. Lisboa: Fundação Calouste Gulbenkian, 2003.

JAMES, A.; JENKS, C.; PROUT, A. Theorizing Childhood Cambridge. Polity Press, 1998.

KOURY, Mauro Guilherme Pinheiro. Relações Imaginárias: a fotografia e o real. In: ACHUTTI, Luiz Eduardo Robinson. (Org.). Ensaio sobre o Fotográfico. Prefeitura Municipal de Porto Alegre/RS, 1998.

MARTINS FILHO, Altino José; PRADO, Patrícia D. (Orgs.). Das pesquisas com crianças à complexidade da infância. Campinas, SP: Autores Associados, 2011.

MENEZES, Sabrina Padilha de Menezes. Cultura Estética Indígena Híbrida: Uma abordagem interdisciplinar acerca da pintura corporal Parkatêjê. 2016. Dissertação. Programa de Pós-Graduação em Dinâmicas Territoriais e Sociedade da Amazônia. Universidade Federal do Sul e Sudeste do Pará. 2016.

MONTANDON, Cléopâtre. Sociologia da infância: balanço dos trabalhos em língua inglesa. Cadernos de Pesquisa, São Paulo: Fundação Carlos Chagas, n. 112, pp. 33-60, mar. 2001.

MÜlleR; Fernanda; CARVAlHO, Ana Maria Almeida Carvalho. (Orgs.). Teoria e Prática na Pesquisa com Criança: diálogos com Willian Corsaro. São Paulo: Cortez, 2009.

PIAGET, Jean. A Construção do Real na Criança. 3. ed. Rio de Janeiro: Zahar Editora, 1979.

PIRES, Sergio Fernandes Senna; BRANCO, Angela Uchoa. Protagonismo infantil: co-construindo significados em meio às práticas sociais. Paidéia (Ribeirão Preto), RibeirãoPreto, v. 17, n. 38, p. 311-320, Dec. 2007.

; BRANCO, Angela Uchoa. Cultura, self e autonomia: bases para o protagonismo infantil. Psic.: Teor. e Pesq., Brasília, v. 24, n. 4, p. 415-421, dec. 2008.

QVORTRUP, Jens. Nove teses sobre “infância como um fenômeno social”. Trad.: Maria Letícia Nascimento. PróPosições, Universidade Estadual de Campinas, Faculdade de Educação. Campinas, v. 22, n. 1, jan. /abr./ 2011, p. 199211.

ROCHA, Simone Maria da; PASSEGGI, Maria da Conceição. Inclusão escolar pela classe hospitalar: o que nos contam as crianças sobre suas experiências educativas no hospital. In: SOUZA, Elizeu Clementino de; PASSEGGI, Maria da 
Conceição; VICENTINI, Paula Perin. (Orgs.). Pesquisa (Auto)biográfica: trajetórias de formação e profissionalização. Curitiba, PR: CRV, p. 107-120, 2013.

ROUSSEAU, J. J. Emilio ou da Educação. Rio de Janeiro: Bertrand Brasil S.A., 1992.

SÁ, Maria José Ribeiro de. Saberes Culturais Tentehar e Educação Escolar Indígena na Aldeia Juçaral. Dissertação. (Mestrado em Educação) - Programa de Pós-Graduação em Educação, Universidade do Estado do Pará, Belém, 2014.

SARMENTO, Manuel Jacinto. Gerações e alteridade: interrogações a partir da sociologia da infância. Educação e Sociedade, Campinas, v. 26, n. 91, p. 361-378, ago. 2005.

. Visibilidade social e estudo da infância. In: VASCONCELLOS, V. M. R.; SARMENTO, M. J. Infância (in)visível. Araraquara: Junqueira e Marin, 2007. p. 25-49.

SIROTA, Régine. Emergência de uma sociologia da infância: evolução do objeto e do olhar. Cadernos de Pesquisa, Fundação Carlos Chagas. São Paulo, n. 112, pp. 7-31, mar. 2001.

TROIS, Loide Pereira. O privilégio de estar com as crianças: o currículo das infâncias. 183 f. Tese (Doutorado) Universidade Federal do Rio Grande do Sul, Faculdade de Educação, Programa de Pós-Graduação em Educação, Porto Alegre, BR-RS, 2012.

VILLAS BOAS, Maria José Villares Barral. \{Per[for(mar)]\}: imagens das crianças no Nêgo Fugido, Acupe/BA. Dissertação (Mestrado) - Programa de Pós-Graduação em Antropologia, Universidade de Brasília, Brasília, 2016. Disponível em: <http://repositorio.unb.br/handle/10482/21068>. Acesso em: 25 jul. 2017.

VYGOTSKY, Lev. Pensamento e linguagem. São Paulo: Martins Fontes, 1991. 


\section{RESUMO}

Este artigo discute as concepções de negação e (in)visibilidade que marcaram a imagem da criança présociológica, bem como, destaca a concepção sociológica de infância que aponta para concepção de criança como ator social e protagonista. Em vista disso, foi constatado que as narrativas fotoetnográficas desvelam e legitimam um protagonismo criativo e subversivo nas relações de alteridade constituídas durante a infância, desse modo, as crianças têm desenvolvido formas de participação e enfrentamento das circunstâncias culturais e sociais das quais participa, o que consiste numa nova imagem sociológica - a da criança protagonista, uma criança que subverte os limites e imposições das culturas visuais e de forma criativa, reinventa modos de ser e de viver na contemporaneidade.

Palavras-chave: Sociologia da Infância. CriançaProtagonista. Fotoetnografia autobiográfica.

\section{THE CHILDREN IN CHILDHOODIMAGES/MARGINS: FROM (IN)VISIBILITY TO SOCIAL PROTAGONISM}

\section{ABSTRACT}

This article discusses the conceptions of negation and invisibility that marked the image of the pre-sociological children, as well as highlights the sociological conception of childhood that points to the conception of children as a social actor and protagonist. In view of this, it was found that the photoetnographic narratives reveal and legitimize a creative and subversive protagonism in the relationships of otherness constituted during childhood, thus, children have developed forms of participation and coping with cultural and social circumstances in which he participates, which is the defense of a new sociological image - that of the child protagonist, a child who subverts the limits and impositions of visual cultures and creatively reinvents ways of being and living in the contemporary world.

Keywords: Sociology of Childhood. Children Protagonist. Autobiographica IPhotoetnograph.

\section{EL NIÑO EN LAS IMÁGENES/MARGENES DE INFANCIA: DA (IN)VISIBILIDAD AL PROTAGONISMO SOCIAL}

\section{RESUMEN}

Este artículo discute las concepciones de negación y (in) visibilidad que marcaron la imagen del niño presociológico, así como, destaca la concepción sociológica de la infancia que apunta a la concepción de niño como actor social y protagonista. Los resultados desvelan que, independientemente de las circunstancias y contextos, los niños ejercen su protagonismo en las relaciones de alteridad constituidas durante la infancia y construyen, creativamente, formas propias de subversión y enfrentamiento de las circunstancias culturales y sociales de las que participa, lo que consiste en una nueva imagen sociológica en la contemporaneidad - la del niño protagonista.

Palabras clave: Sociología de la Infancia. Niño Protagonista. Fotoetnografia autobiográfica. 